\title{
EFFECTS OF DIFFERENT IMPROVEMENT TREATMENTS ON BOTANICAL COMPOSITION AND SEDIMENT MOVEMENT ON GRAZED AND ENCLOSED RANGE SITES
}

\author{
Tamer COSKUN $N^{1}$, Mahmut DASCI ${ }^{2 *}$, M. Kerim GULLAP ${ }^{2}$, Binali COMAKLI ${ }^{2}$, N.Zeynep YILDIRIM ${ }^{3}$, \\ Hulya BAKIR ${ }^{l}$, Hikmet BIRHAN ${ }^{l}$ \\ ${ }^{1}$ Ataturk University, Faculty of Agriculture, Department of Field Crops, Erzurum, TURKEY \\ ${ }^{2}$ Republic of Turkey Ministry of Food, Agriculture and Livestock, East Anatolian Agricultural Research \\ Institude, Erzurum, TURKEY \\ ${ }^{3}$ Directorate of Provincial Food Agriculture and Livestock, Erzurum, TURKEY \\ *Corresponding author: mtasci@atauni.edu.tr
}

Received: 31.05.2016

\begin{abstract}
This study was carried out on heavily grazed rangelands in Erzurum, during the years 2006-2009, for 4 years period. In this study, four treatments that included artificial pasture, oversowing, fertilization and control were applied on grazed and enclosed rangeland sites. A mixture of Crested wheatgrass (Agropyron cristatum), alfalfa (Medicago sativa) and smooth brome (Bromus inermis) was used for rangeland seeding. Ammonium sulfate and Triple Super Phosphate was applied on fertilization plots in sites grazed and enclosed site. Botanical composition was determined by line intercept methods. After each erosive rain event, the amount of soil (sediment) was determined in each plot. Across of four years, fertilization increased the grass proportion, decreased other species proportion and sediment yield in both sites. Under grazing, over sowing increased the grass proportion, and decreased other species proportion. Lower grass, higher legumes, higher other species proportion and higher sediment yield determined in the third year compared to other years in both sites. The enclosed site had higher grass, lower legumes, other species proportion and sediment yield than the grazed one. Results of this study showed fertilization and oversowing treatment can be effective for soil protection in enclosed and grazed rangelands, similar to this study area. Also, combined with short term enclosure treatment the other improvement treatments can recommend for rangeland restoration and soil protection.
\end{abstract}

Keywords: Enclosure, grazing, improvement, rangeland, sediment movement

\section{INTRODUCTION}

Rangelands play a major role in supporting human populations such as food production, water regulation, energy supply, erosion control, and recreation (Altin et al. 2005; Greiner et al. 2009; Holechek et al. 2011).

Understanding soil-plant relationships are very important in rangeland management and planning. These correlations can help managers for production and prevent financial damages (Shadkami and Bibalani 2011). Because the soil is the primary component of rangeland ecosystems and it has an important function for forage production in an area with particular climate (NRC 1994; Holechek et al. 2011). The plants are vital for the protection of the soil against to the erosive forces. Their roots help the soil in place and above ground biomass and crop residues especially the foliage, reduce the impact of falling raindrops, the movement of surface water and increase its infiltration into the soil (NRC 1994; Acikgoz 2001; Wall 1987; Livingstone 1991). Soil erosion potential increases as the vegetation cover of plants or crop residues decrease (Sanjari 2011). If the vegetation is degraded by heavy grazing or other factors such as fire and drought, soil erosion can reduce pasture production (NRC 1994). To protect the soil from erosion it is important to maintain enough vegetation cover (Holechek et al. 2011).

In rangelands, suitable grazing management must be practiced carefully for high production. If the pastures are degraded by the effects of environmental forces the restoration of these areas may take too long period because soil formation processes work slowly, especially in arid and semiarid climates (NRC 1994; Gokkus and Koc 1996; Holechek et al. 2011). There are many restoration practices to improve the forage production, vegetation cover and increase quality plant species. Fertilization, oversowing, artificial pasture and suitable stocking level or temporary enclosure to animal grazing may be effective in improving rangeland soil and vegetation (Khumalo et al. 2007; Altin et al. 2011). 
However, there are several factors causing grassland degradation to different grades, grazing intensity is one of the most important causes of degradation in the world's arid and semiarid rangelands (Snyman 2005; Altin et al. 2005; Holechek et al. 2011). Overgrazing has a number of negative impacts on rangelands, often including an increase in undesirable vegetation or a loss in vegetation cover and biomass (Herbel and Pieper 1991; Tongway et al. 2003; Comakli et al. 2008; Gadzia and Sayre 2009; Comakli et al. 2012; Holechek et al. 2011) and it leads not only to a decline of biodiversity (Wu 1997), grass and animal production, but also to the deterioration of the environment (Zhang 1995). Also, heavy grazing has negative effects on soil physical and chemical properties (Beukes and Cowling 2003).

In Turkey, farmers have used the rangeland traditionally as long as the climatic conditions are favorable for grazing. On rangelands, grazing starts with the melt of snow in spring and continues until the first snowfall in autumn, commonly not taken into account the basic principles of range management such as proper stocking rate, frequency, timing, and rotational grazing. Many rangelands have further deteriorated due to excessive and uncontrolled grazing, practiced in low rainfall and droughts conditions. Heavy grazing pressure results in a number of negative impacts, including an increase in undesirable vegetation or a loss in vegetation cover, the composition of the plant communities and the productivity of the rangelands (Altin et al. 2011).

The aim of this study was to evaluate the effects of different improvement treatments on botanical composition and soil loss on rangelands in Erzurum, Turkey. Some recommendation will be made regarding improvement plant species quality and reduction of soil loss by movement of surface runoff for rangeland users and scientists.

\section{MATERIALS AND METHODS}

This study was carried out on heavily grazed rangeland in Erzurum, during the years 2006-2009, for 4 years period. This pasture has been grazed intensively for many years. The pasture was delineated and divided two sites. One of them was fenced in the year 2005 to protect animal grazing. Two range site with similar soil properties (Table 1) and topography. The degree of slope and aspect were the same on both sites. The treatment plots were separated by sheet metal from each other to prevent water runoff and to the bottom of all plots, accumulation tanks were conducted to collect moved soil and water from plots (Figure 1). After each erosive rain, the amount of soil (sediment) was weighted in each tank.

Table 1. Some physical and chemical soil analysis results of treatment plots

\begin{tabular}{|c|c|c|c|c|c|c|c|c|}
\hline & Saturation Stbl. & pH & $\begin{array}{c}\mathrm{K}_{2} \mathrm{O} \\
\left(\mathrm{kg} \mathrm{da}^{-1}\right)\end{array}$ & $\mathrm{P}_{2} \mathrm{O}_{5}\left(\mathrm{~kg} \mathrm{da}^{-1}\right)$ & $\mathrm{CaCO}_{3}(\%)$ & Organic Matter (\%) & Field Capasity (\%) & Wilting Point (\%) \\
\hline \multicolumn{9}{|c|}{ Enclosed } \\
\hline Oversowing & 54.34 & 6.71 & 151.00 & 10.53 & 0.74 & 4.89 & 23.50 & 13.66 \\
\hline Fertilization & 55.68 & 6.45 & 131.33 & 17.96 & 0.61 & 5.15 & 24.88 & 14.01 \\
\hline Art. Pasture & 53.68 & 6.54 & 135.00 & 10.05 & 0.63 & 4.40 & 22.92 & 13.51 \\
\hline Control & 54.68 & 6.74 & 144.00 & 7.50 & 0.59 & 4.93 & 23.68 & 13.71 \\
\hline \multicolumn{9}{|c|}{ Grazed } \\
\hline Oversowing & 52.34 & 6.44 & 146.00 & 11.33 & 0.52 & 5.30 & 24.35 & 13.45 \\
\hline Fertilization & 54.34 & 6.37 & 144.33 & 17.58 & 0.61 & 5.23 & 24.56 & 13.68 \\
\hline Art. Pasture & 48.34 & 6.36 & 142.67 & 11.87 & 0.65 & 5.06 & 23.85 & 13.25 \\
\hline Control & 54.34 & 6.49 & 137.33 & 8.52 & 0.61 & 5.24 & 24.65 & 14.12 \\
\hline
\end{tabular}

(10.5 $\mathrm{kg} \mathrm{ha}^{-1}$ ) in the mixture (Bakir 1985). The experiment

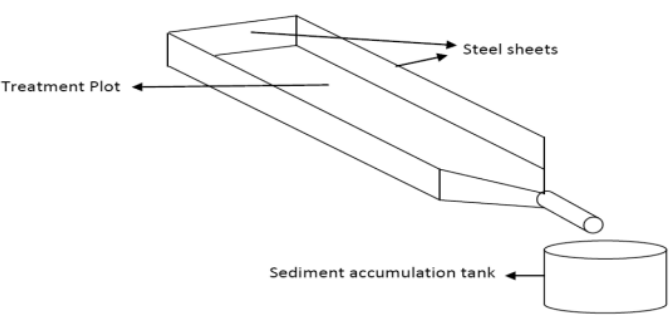

Figure 1. The design of the treatment plots on experiment area

In this study, four treatments (Artificial pasture, oversowing fertilization and control) were applied on grazed and enclosed rangeland sites. Three forage species, crested wheatgrass (Agropyron cristatum), alfalfa (Medicago sativa) and smooth brome (Bromus inermis) were mixed to establish for seeding. The same mixture were used for artificial and oversowing plots. The rate of forage plant species was $30 \%$ alfalfa $\left(6 \mathrm{~kg} \mathrm{ha}^{-1}\right), 35 \%$ smooth brome $\left(14 \mathrm{~kg} \mathrm{ha}^{-1}\right)$ and $35 \%$ crested wheatgrass was designed in a split model of randomized complete block design, replicated three times. The size of treatment plots was $9 \mathrm{~m}^{2}$. Ammonium sulfate $\left(60 \mathrm{~kg} \mathrm{ha}^{-1}\right)$ and Triple Super Phosphate $\left(40 \mathrm{~kg} \mathrm{ha}^{-1}\right)$ was applied on fertilization plots in both sites (grazed and enclosed). Some physical and chemical soil analysis of study sites was made and the results were showed in Table 1.

The precipitation values of experiment areas for study years and long-term average (LTA) (1990-2009) were shown in Table 2.

Botanical composition of rangeland was determined at the flowering periods of dominant plant species, using line interception method (developed by Canfield 1941) in each year.

The data related to the botanical composition were in percentages and were arcsine square root transformed to improve the normality of data. Analysis of Variance (ANOVA) was computed by SAS (2002) GLM with mean separation according to the LSD test. 
Table 2. The precipitation values of experiment areas in study years and long term average (1990-2009)

\begin{tabular}{cccccccccccccc}
\hline & Jan. & Feb. & Mar. & Apr. & May & June & July & Aug. & Sept. & Oct. & Nov. & Dec. & Total \\
\hline 2006 & 17.8 & 10.9 & 13.4 & 77.4 & 41.6 & 19.2 & 20.7 & 3.5 & 29.2 & 90.1 & 25.3 & 8.3 & 357.4 \\
2007 & 13.5 & 8.4 & 20.4 & 79.4 & 61.2 & 61.8 & 41.9 & 30.4 & 0.1 & 33.7 & 68.1 & 17.7 & 436.6 \\
2008 & 16.4 & 10.3 & 18.6 & 45.0 & 58.0 & 41.0 & 11.2 & 16.6 & 22.7 & 39.6 & 14.6 & 23.9 & 317.9 \\
2009 & 2.3 & 18.8 & 51.1 & 42.3 & 43.2 & 76.2 & 29.2 & 22.8 & 43.7 & 51 & 41.4 & 15.1 & 437.1 \\
LTA & 14.5 & 20.6 & 35.1 & 57.1 & 64.6 & 42.6 & 23.1 & 14.3 & 21.8 & 43.8 & 30.0 & 23.6 & 391.2 \\
\hline
\end{tabular}

\section{RESULTS AND DISCUSSION}

The runoff events were a result of short duration, highintensity rainfall events. Among the total rainfall events, only 18 (total $243.9 \mathrm{~mm}$ ) produced measurable sediment yield occurred during the observation period from April 2006 to July 2009 in both sites.

Based on four years results, grasses, legumes, and other families ratio were showed a significant difference $(\mathrm{p}<0.01)$ among treatments in both sites. Year, site and treatment had significant effects on grasses, legume, and other families' ratio.

The enclosed site had higher grass lower legume and other families' ratio than grazed site (Table 3 ).

Table 3. Botanical composition values (\%) and sediment movement $\left(\mathrm{kg} \mathrm{ha}^{-1}\right)$ on enclosed and grazed range site.

\begin{tabular}{ccccc}
\hline & Grasses & Legumes & Others & $\begin{array}{c}\text { Sediment } \\
\left.\text { Yield (kg ha }{ }^{-1}\right)\end{array}$ \\
\hline Enclosed & $69.85 \mathbf{A}$ & 12.93 & $17.53 \mathbf{B}$ & $252.90 \mathbf{B}$ \\
Grazed & $57.56 \mathbf{B}$ & 13.40 & $29.00 \mathrm{~A}$ & $489.48 \mathbf{A}$ \\
\hline
\end{tabular}

As the study years advanced, the sediment yield tended to increase (except last year) and the sediment yield was the lowest in the first study year and the highest yield was in the third study year on both sites. Sediment yield showed a significant difference $(p<0.01)$ between study years, treatments and sites. The average of four study years grazed site produced higher sediment yield than enclosed site. Sediment yield was the highest on artificial pasture treatment plots, the lowest on fertilization treatment plots on both sites (Table 3, 4, 5).

The fertilization treatment plots had the highest grass and lowest legume ratio on enclosed site. The lowest grass ratio was determined on control plots of enclosed site. Grass ratio did not differ between artificial pasture and oversowing treatment plots. Legume ratio was the highest on artificial pasture treatment plots, and other families ratio was the highest on control plots, the lowest on artificial pasture and fertilization treatment plots (Table 4).

Table 4. Changing of botanical composition (\%) and sediment movement $\left(\mathrm{kg} \mathrm{ha}^{-1}\right)$ in different treatment plots on enclosed and grazed range sites

\begin{tabular}{|c|c|c|c|c|}
\hline & \multicolumn{4}{|c|}{ Enclosed } \\
\hline & Grasses & Legumes & Others & Sediment Yield $\left(\mathrm{kg} \mathrm{ha}^{-1}\right)$ \\
\hline Control & $64.73 \mathrm{C}$ & $15.25 \mathrm{~B}$ & $21.70 \mathrm{~A}$ & $42.43 \mathbf{B}$ \\
\hline Fertilization & $76.78 \mathbf{A}$ & $7.91 \mathbf{D}$ & $15.32 \mathbf{C}$ & $31.00 \mathrm{C}$ \\
\hline Artificial pasture & $68.28 \mathbf{B}$ & $17.28 \mathbf{A}$ & $13.95 \mathrm{C}$ & $145.02 \mathrm{~A}$ \\
\hline \multirow[t]{3}{*}{ Oversowing } & $69.63 \mathrm{~B}$ & $11.27 \mathrm{C}$ & $19.16 \mathbf{B}$ & $34.46 \mathrm{C}$ \\
\hline & \multicolumn{4}{|c|}{ Grazed } \\
\hline & Grasses & Legumes & Others & Sediment Yield $\left(\mathrm{kg} \mathrm{ha}^{-1}\right)$ \\
\hline Control & $51.73 \mathrm{~B}$ & $13.23 \mathrm{~B}$ & $34.98 \mathrm{~A}$ & $80.27 \mathrm{C}$ \\
\hline Fertilization & $63.82 \mathrm{~A}$ & $9.43 \mathbf{D}$ & $26.77 \mathrm{C}$ & $59.60 \mathrm{D}$ \\
\hline Artificial pasture & 49.43 B & $20.33 \mathbf{A}$ & $30.24 \mathbf{B}$ & $261.18 \mathrm{~A}$ \\
\hline Oversowing & $65.27 \mathbf{A}$ & $10 . .65 \mathrm{C}$ & $24.04 \mathrm{D}$ & $88.43 \mathbf{B}$ \\
\hline
\end{tabular}

Similar to the enclosed site, on grazed site fertilization treatment plots had the lowest legume ratio; control plots had the highest other families' ratio and artificial pasture treatment plots had the highest legume ratio. Grass ratio did not differ between fertilization and oversowing treatment plots. Also, grass ratio did not show any significant difference $(\mathrm{p}<0.01)$ between control and artificial pasture treatment plots (Table 4).
The highest grass ratio was in years 2006, 2007 and 2009 , and the lowest grass ratio determined in the year 2008 on enclosed site. The year 2008 had the highest legume ratio; the year 2006 had the lowest legume ratio. There was no significant difference $(\mathrm{p}<0.01)$ between the years 2007 and 2009 for legume and other families ratio. The other families' ratio was the highest in the year 2008. Sediment yield was the highest in the year 2008, the lovest was in the year 2006 in enclosed site. 
Table 5. Changing of botanical composition (\%) and sediment movement $\left(\mathrm{kg} \mathrm{ha}^{-1}\right)$ on enclosed and grazed range site in study years

\begin{tabular}{|c|c|c|c|c|}
\hline \multicolumn{5}{|c|}{ Enclosed } \\
\hline & Grasses & Legumes & Others & Sediment Yield $\left(\mathrm{kg} \mathrm{ha}^{-1}\right)$ \\
\hline 2006 & $75.07 \mathrm{~A}$ & $5.73 \mathrm{C}$ & $19.20 \mathbf{B}$ & $10.24 \mathrm{D}$ \\
\hline 2007 & $72.96 \mathbf{A}$ & $13.18 \mathbf{B}$ & $13.87 \mathrm{C}$ & $87.04 \mathbf{B}$ \\
\hline 2008 & $58.00 \mathbf{B}$ & $19.92 \mathbf{A}$ & $23.25 \mathrm{~A}$ & $109.78 \mathbf{A}$ \\
\hline 2009 & $73.39 \mathrm{~A}$ & $12.89 \mathbf{B}$ & $13.75 \mathrm{C}$ & $45.84 \mathrm{C}$ \\
\hline \multicolumn{5}{|c|}{ Grazed } \\
\hline & Grasses & Legumes & Others & Sediment Yield $\left(\mathrm{kg} \mathrm{ha}^{-1}\right)$ \\
\hline 2006 & $65.76 \mathrm{~A}$ & $6.29 \mathrm{D}$ & $27.82 \mathbf{B}$ & $14.09 \mathrm{D}$ \\
\hline 2007 & $56.78 \mathrm{C}$ & $16.06 \mathbf{B}$ & $27.17 \mathbf{B}$ & $137.33 \mathbf{B}$ \\
\hline 2008 & $47.58 \mathbf{D}$ & $17.42 \mathbf{A}$ & $35.00 \mathrm{~A}$ & $249.28 \mathbf{A}$ \\
\hline 2009 & $60.13 \mathbf{B}$ & $13.87 \mathrm{C}$ & $26.04 \mathbf{B}$ & $88.78 \mathrm{C}$ \\
\hline
\end{tabular}

In grazed site, the highest grass ratio was in the year 2006 and the lowest was in the year 2008. Legume ratio and sediment yield were the highest in the year 2008, the lowest in the year 2006. The highest other families ratio was in the year 2008 and there was no significant difference between the years 2006, 2007 and 2009 (Table $5)$.

Rangelands are unsuitable for cultivation and which are as a source of forage for free-ranging native and domestic animals as well as a source of wildlife (Stoddart et al. 1975). They also play important roles in water and soil protection.

In general, the quantity of grass is increased by the effects of fertilization, especially nitrogen, while legumes and other species decrease (Delpech 1966; Jones and Winans 1967). The data obtained in this study indicate that fertilization treatment has a considerable influence on botanical composition.

Grasses are the most common plant families and the legumes are the minor component of the vegetation of natural pastures in Turkey (Altin 1975; Gokkus 1984; Koc 1995; Basbag et al. 1997; Bakoglu 1999; Comakli et al. 2008). In this study, grasses had the highest proportion; except artificial pasture plots of enclosed site, the legumes had the lowest in botanical composition of all treatment plots in both sites. The reason of the high grass, low legume and other species proportions in fertilization plots may be attributed to the increasing effects of nitrogen on grasses (Delpech 1966; Jones and Winans 1967) and suppressing effects of the grasses on the legumes and other species proportion. As the plant proportion increases, the sediment yield from pasture surface decreases because increasing of infiltration decreases water runoff from the soil surface (Wall 1987; Livingstone 1991; Sanjari 2011). As expected the legume proportion was higher in artificial pasture plots, with seeded alfalfa, than that of the other treatment plots. In artificial pasture plots of enclosed site, due to the plots was planted with two grasses and a legume species, the other species was dominated by these species. The high sediment yield in artificial pasture plots can most probably relate to mechanical disturbance of soil (Junge et al. 2008). On the other hand, decreasing of the covering, the sediment movement increases (Lal 1993).
The effectiveness of fertilization on botanical composition may be related to some ecological factors, as precipitation and soil nutrient content. The reason of the lower grasses, higher other families' proportion in third study year than that of the other study years can be attributed to the lower rainfall recorded in this year than that of the other years. Also, in addition to fertilization, enclosure to grazing can be stimulated the percentage of the grasses. On the other hand, unlike to expected, grasses and legumes declined in 2007 and 2009 years with higher rainfall due to the grasses and legumes selectively grazed by animals in grazed site. The reason for the lowest sediment yield in the first study year can be related to high grass proportion, less total and seasonal rainfall amount, in addition to low erosive rainfall amount and number, especially occurred in summer months and the snow uncovered months (Table 2). Thus, sediment yield was recorded as the lowest in all treatment plots in the first study year. Despite the low total rainfall in third study year, high rainfall values recorded in summer and autumn months. The reason for higher sediment yield recorded in third study year can be attributed to the high rainfall values recorded in summer and autumn months and the lowest grass species ratio. Thus, it is expressed that small canopy cover and the high rainfall intensity can have increasing effects on soil loss; it can be prevented or reduced by appropriate crop management using grass and legumes for cover crops (Junge et al 2008).

Enclosure to animal grazing may stimulate the grasses and legumes, suppress the other plant species (Comakli et al. 2012). Increasing plant cover keeps the soils stable (Acikgoz 2001), especially grasses, by intensive root systems. The reasons of higher grasses, legumes; lower other species and sediment yield in enclosed site can be attributed to the positive effect of enclosure treatment. Related with high plant cover, the sediment yield was lower in enclosed site than grazed site. Also, the movement of sediment yield can be increased by the effects of the hooves of grazing animal on grazed site.

The interaction of site and treatment (Figure 2,5(a)); year and treatment (Figure 3,5(c)); year and site (Figure 4, 5(b)) had a significant effect on grass, legume and others ratios and sediment movement. Also, year and site and treatment had a significant effect on grass, legume and other families' ratios and sediment yield. 

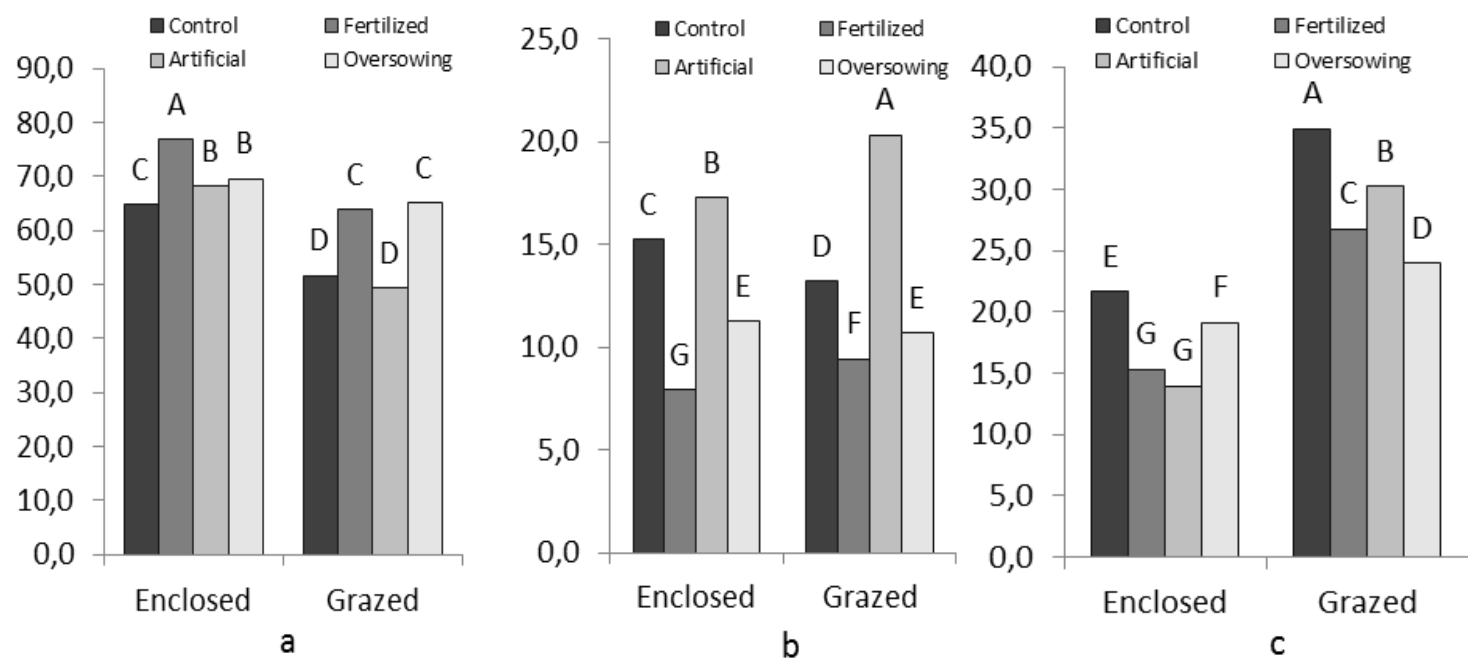

Figure 2. The effects of site $x$ treatment interaction on grasses (a). legumes (b) and other families (c) ratios.
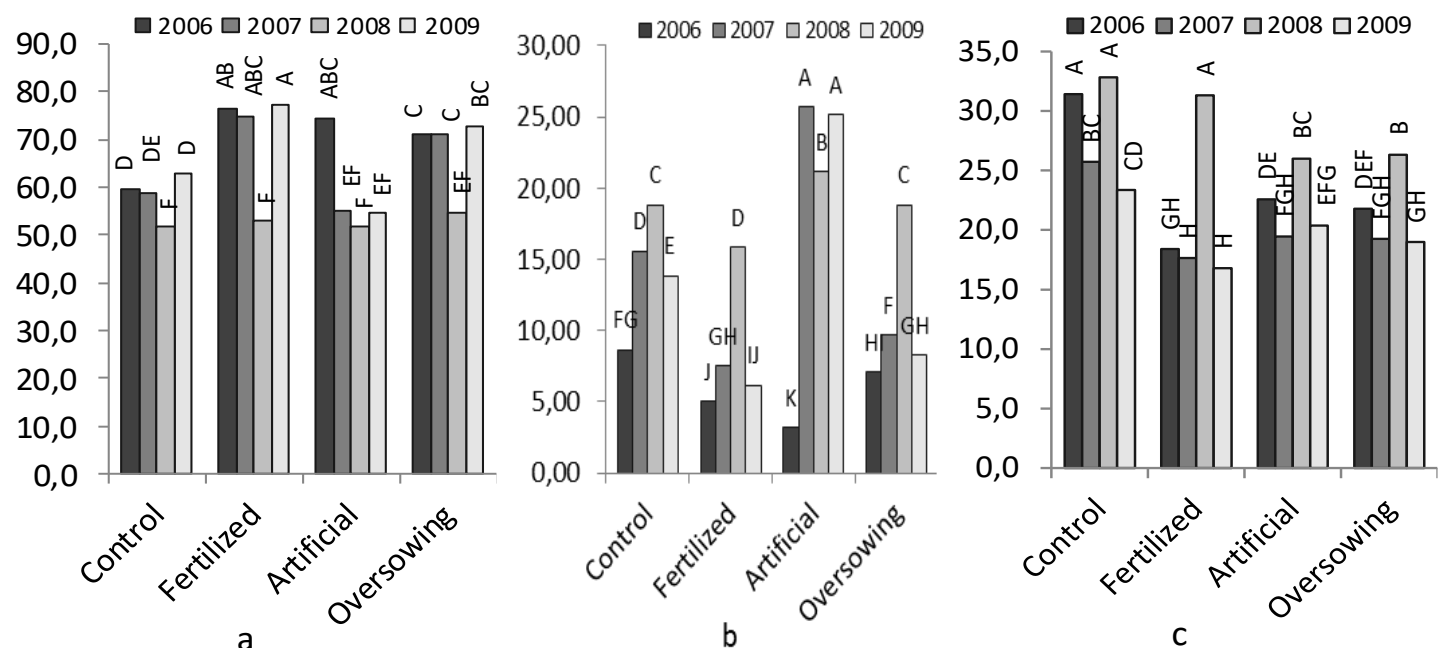

Figure 3. The effects of year $x$ treatment interaction on grasses (a). legumes (b) and others (c) ratios.
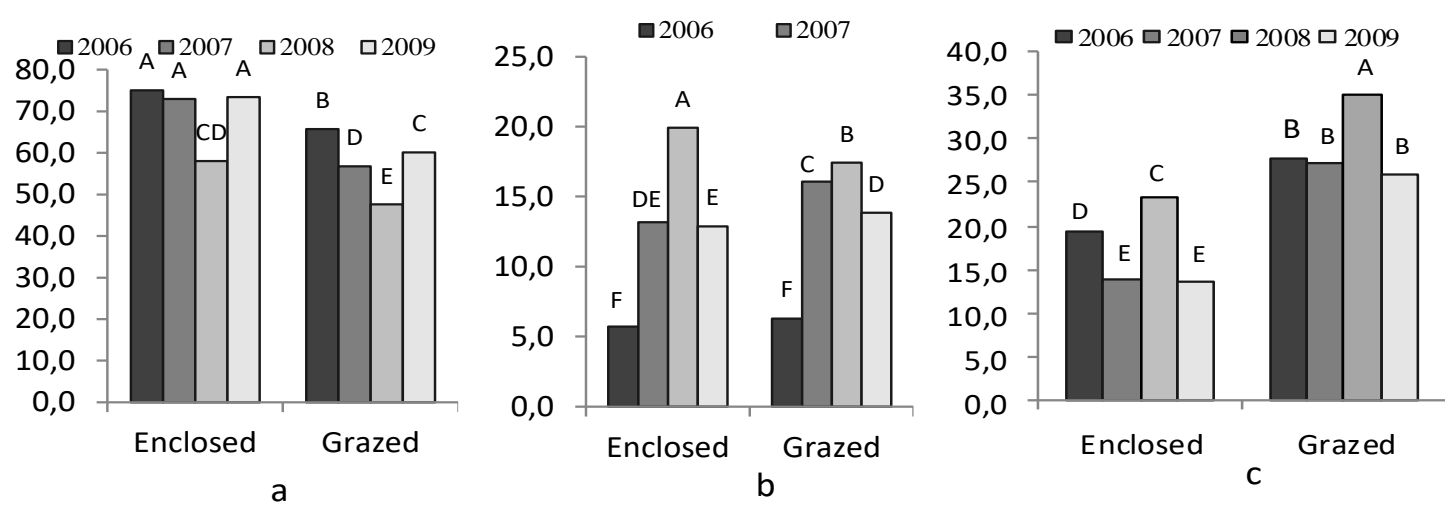

Figure 4. The effects of year $x$ site interaction on grasses (a), legumes (b) and other families (c) ratios. 


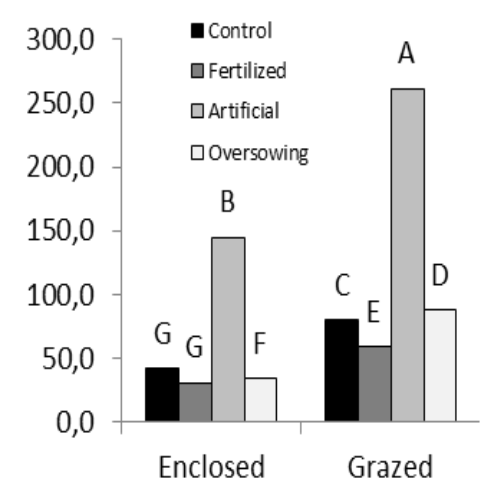

a

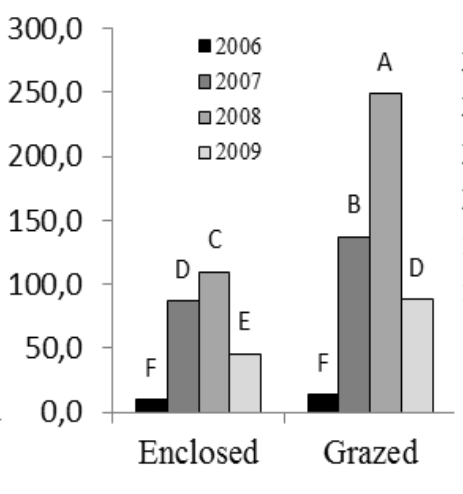

$\mathrm{b}$

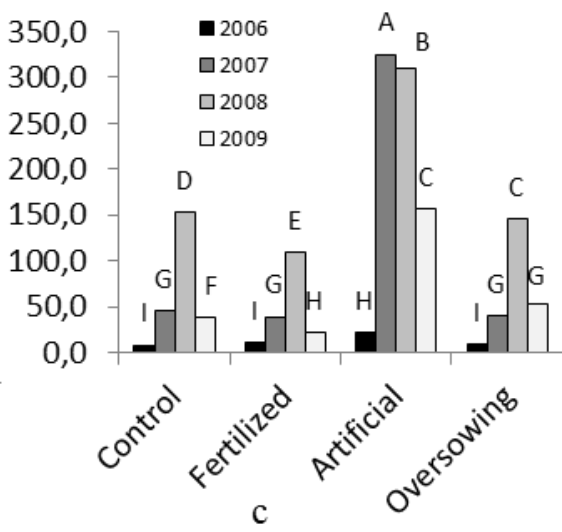

Figure 5. The effects of site and treatment (a); year and site (b); year and treatment (c) interactions on sediment yield

The interactions of site and treatment, year, and treatment, year and site were significant with regard to the grass, legume and the other species ratio and sediment yield on rangeland. These results can most probably relate to the combined effects of grazing and enclosure treatments, different improvement applications and climatic conditions, occurred in study years.

\section{CONCLUSIONS}

Results of this study indicate that heavy grazing in pastures increases the sediment movement and leads to losing of productive topsoil. Fertilization and oversowing treatments can be effective for soil protection in enclosed and grazed rangelands. In addition to enclosure treatment for short-term periods, all treatments were effective in increasing of grass, decreasing of the other plant species. Although artificial pasture treatment can be suggested to increase high-quality legumes proportion, decrease lowquality other species proportion on grazed and enclosed site the sediment movement can be increased in this treatment, suitable management practices should be continued for a few years carefully.

\section{ACKNOWLEDGEMENTS}

The autors express their gratitude to Prof. Dr. Jery L. Holechek for reviewing.

\section{LITERATURE CITED}

Açıkgöz, E. 2001. Forage crops. Foundation of Strengthen of Uludag University. No: 182. Bursa.

Altin, M. 1975. An investigation the effects of Nitrogen, Phosphorus and Potassium fertilizers on yield, crude protein and crude ash ratio and plant species composition of natural meadow and rangeland in Erzurum ecological condition. Ataturk Univ. Yay No: 326, Agr. Fac. No: 159, Res. Series No: 95, Erzurum, $141 \mathrm{~s}$.

Altin, M. A. Gokkus and A. Koc, 2005. Pasture-rangeland improvement. T. C. Ministry of Agriculture of Rural Affairs, General Directorate of Agricultural Production and Development, Ankara, 468 p.

Altin, M., A. Gokkus and A. Koc. 2011. Meadow-pasture management. T. C. Ministry of Agriculture of Rural Affairs, General Directorate of Agricultural Production and Development, Ankara.
Bakır, Ö. 1985. Meadow and Pasture Improvement. Ankara University, Agric. Fac. Pub. No. 947, Ankara.

Bakoglu, A. 1999. The comparison of some soil and plant characteristics of two different rangeland sites, grazed and ungrazed. Ataturk Univ. Graduate School of Natural and Applied Sciences, Department of Field Crops (Unpublished Ph.D. thesis), Erzurum.

Bakoglu, A. A. Koc and A. Gokkus, 1999. Some characteristics of the common plants of range and meadows in Erzurum in relation to lifespan, beginning with the flowering and forage quality. Turkish J. Agric. and Forestry 23(4): 951-957.

Basbag, M., İ. Gül, and V. Saruhan. 1997. Investigation of yield and composition of protected rangeland in Diyarbakir. Turkey II. Field Crops Cong. 22-25 September 1997, Samsun, 499-503.

Beukes, P. C. and R. M. Cowling. 2003. Non-selective grazing impacts on soil properties of the Nama Karoo. J. Range Manage. 56: 547-552.

Canfield, R. H. 1941. Application of the line interception method in sampling range vegetation. J. For. 39: 388-394.

Comakli, B. M. Dasci and A. Koc. 2008. The effects of traditional grazing practices on upland rangeland vegetation and forage quality. Turkish J. Agric. and Forestry 32:259265.

Comakli, B. T. Oner and M. Dasci. 2012. Changing of the vegetation on rangeland sites with different using history. Iğdır Univ. J. Inst. Sci. \& Tech.2(2):75-82.

Delpech, R. 1966. An agronomic application of experimental phytosociology: a contribution to the study of the effect of mineral fertilizer on permanent grasslands in the Seano Valley. Fr. C. R. hebd. Seano. Acad. Agr. Fr. 52(1): 50-60.

Gadzi, K. and N. Sayre, 2009. Rangeland health and planned grazing, Field Guide. The Quivira Coalition, Earth Works Institute, the New Ranch Network.

Gokkus, A. 1984. Investigations on dry yield, crude protein yield and botanical composition on natural rangelands of Erzurum, practiced different improvement practiced. (Ph.D. thesis). Ataturk Univ. Graduate School of Natural and Applied Sciences, Department of Field Crops, Erzurum.

Gokkus, A. and A. Koc. 1996. Plant-soil relation in plowed rangeland. Mersin Univ. Engineering Fac. AgricultureEnvironment Relations Symposium Sustainable Using of Natural Sources Proceedings Book. 13-15 May 1996, Mersin, 336-344.

Greiner, R., I. Gordon and C. Cocklin. 2009. Ecosystem services from tropical savannas: economic opportunities through payments for environmental services. Rangeland Journal 31:51-59. 
Herbel, C. H. and R. D. Pieper. 1991. Grazing management. In semiarid lands and deserts: Soil resources and reclamation (Ed.J.Skujin), Marcel Dekker, 361-385, New York.

Holechek, J. L., R. D. Pieper and C. H. Herbel. 2011. Range management principles and practices. Sixth edition. Prentice Hall, Upper Saddle River, New Jersey, USA. 444 p.

Jones, M. B. and S. S. Winans. 1967. Subterranean clover versus nitrogen fertilized annual grasslands: Botanical composition and protein content. Journal of Range Manag. 20(1): 8-12.

Junge, B., R. Abaidoo, D. Chikoye and K. Stahr. 2008. Soil conservation in Nigeria. Past and present on-station and onfarm initiatives. Soil and Water Conservation Society, Ankeny, Iowa, USA. Available at: www.swcs.org

Khumalo, G., J. L. Holechek, M. Thomas and F. Molinar. 2007. Long-term vegetation productivity and trend under two stocking levels on Chihuahuan Desert Rangeland. Rangeland Ecol. Manage., 60:165-171.

Koc, A. 1995. Effects of topography, soil moisture and temperature on some properties of rangeland vegetation. (Ph.D. thesis) Ataturk Univ. Graduate School of Natural and Applied Sciences, Department of Field Crops, Erzurum.

Lal, R. 1993. Soil erosion and conservation in West Africa. In World soil erosion and conservation, ed. D. Pimentel, 7-28. Cambridge: Cambridge University Press.

Livingstone, I. 1991. Livestock management and overgrazing among Pastoralists. Ambio 20:80-85.

National Research Council. 1994. Rangeland Health. New Methods to Classify, Inventory, and Monitor Rangelands. National Academy Press, Washington, D.C. 182 p.

Sanjari, G. 2011. Short-term intensive rotational grazing in the native pasture: I. Results of a plot scale experiment on runoff and soil loss in association with catchment scale's outcomes. Australian Centre for International Agricultural Research,
World Congress on Conservation Agriculture. http://aciar.gov.au/files/node/13992/ short term intensive rotational grazing in native 16680.pdf. (Accessed May 25, 2016).

Shadkami, H. and Gh. H. Bibalani. 2011. Overground biomass characteristics of genera single Species Iran (Cnicus benedictus) in northwest Iran (till area of shape star). International Journal of Academic Research 3(1). January 2011, Part III

Stoddart, L. A. Smith and T. Box. 1975. Range Management. New York, USA, McGraw-Hill Book Co.

Snyman, H. A. 2005. Rangeland degradation in a semi-arid South Africa. I: influence on seasonal root distribution, root/shoot ratios, and water-use efficiency. Journal of Arid Environments 60:457-481.

SAS Inst. Inc 2002. SAS/STAT user's guide. Version 8. Cary, NC: SAS Institute Inc. 528 p.

Tongway, D. J., A. D. Sparrow and M. H. Friedel. 2003. Degradation and recovery processes in arid grazing lands of central Australia. Part I: soil and land resources. Journal of Arid Environments 55:302-326.

Wall, G. and S. Omafra. 1987. Soil erosion causes and effects. Ontario factsheet, Ministry of Agriculture, Food and Rural Affairs. http://www.thegeographeronline.net/uploads/2/6/6/2/266293 56/soil_erosion_causes_and_effects.pdf (Accessed 25 May, 2016).

$\mathrm{Wu}, \quad$ N. 1997. Indigenous Knowledge and Sustainable Approaches for the Maintenance of Biodiversity in Nomadic Society - Experience from Eastern Tibetan Plateau. Die Erde, 128: 67-80.

Zhang, Z. 1995. The effect and causes of grassland degeneration (In Chinese). Pratacultural Science 12 (6):1-5. 